\title{
OXYTETRACYCLINE RESIDUES IN HONEY ANALYZED BY LIQUID CHROMATOGRAPHY WITH UV DETECTION
}

\author{
Anna Gajda ${ }^{1 *}$, Andrzej Posyniak ${ }^{1}$, \\ Andrzej Bober ${ }^{2}$, Tomasz Błądek ${ }^{1}$, Jan Żmudzki ${ }^{1}$ \\ ${ }^{1}$ Department of Pharmacology and Toxicology, National Veterinary Research Institute, \\ Partyzantów 57, 24-100 Pulawy, Poland \\ ${ }^{2}$ Department of Honey Bee Diseases, National Veterinary Research \\ Institute, Partyzantów 57, 24-100 Pulawy, Poland \\ *corresponding author: anna.gajda@piwet.pulawy.pl
}

Received 13 July 2012; accepted 10 April 2013

$\mathrm{S}$ u m m a r y

A liquid chromatography method with UV detection for determination of oxytetracycline (OTC) in honey has been developed. The samples were extracted with the solution of oxalic acid. The clean-up procedure was performed by solid phase extraction (SPE) using polymeric Strata X and carboxylic acid cartridges. Chromatographic separation was carried out on the Luna C8 analytical column with mobile phase consisting of acetonitrile- $0.02 \mathrm{M}$ oxalic acid. The method has been successfully validated according to the requirements of the European Decision 2002/657/EC and this method is used in routine control of oxytetracycline in honey samples. The limit of detection (LOD) and limit of quantification (LOQ) of the presented method were 10 and $12.5 \mu \mathrm{g} / \mathrm{kg}$, respectively. The developed method has also been verified in quantitative determination of oxytetracycline residues in honey after experimental treatment with this product in bee colonies.

Keywords: oxytetracycline, honey, residues, validation, depletion, HPLC-UV method.

\section{INTRODUCTION}

American foulbrood (AFB) and European foulbrood (EFB) are destructive, infectious bacterial diseases in honeybees (Apis melifera), which can severely decrease the honey bee population and honey production (Gojmerac, 1980). American foulbrood spores are highly-resistant and can remain vital in combs and honey for many years. To control outbreaks of these infections in honeybee colonies, tetracyclines are shown to be effective. These compounds are wide spectrum antibiotics with properties to prevent the growth of bacteria by inhibition of protein synthesis. Oxytetracycline belongs to the tetracyclines group and is commonly applied by beekeepers.

There are many regulatory problems and inconsistencies associated with the use of the oxytetracycline antibiotic in apiculture. According to The European Medicine
Agency (EMEA) summary opinion, regarding the establishment of maximum residue limit (MRL) for oxytetracycline in honey, a provisional MRL of $25 \mu \mathrm{g} / \mathrm{kg}$ has been set, which will expire on 01.01.2014, for the parent drug of OTC and its 4-epimer (EMEA Summary Report, 2008). However, in accordance with the Regulation (EC) No 470/2009 and Commission Regulation (EU) No 37/2010, no MRL exists for this compound in honey and it is banned in Europe. So, the European Union (EU) does not allow the use of oxytetracycline, or anything else from the tetracyclines group, for treatment of honeybees. The presence of any detectable residues of these antibiotics could mean that the honey cannot be commercialized in the EU. Unlike the EU countries, other countries like the United States and Brazil, allow the use of OTC for treatment of $\mathrm{AFB}$ and the maximum residue limit for 
this compound has been set as $200 \mu \mathrm{g} / \mathrm{kg}$ (USFDA, 2008; Peres et al., 2010).

Oxytetracycline can persist in honey and may lead to drug resistance, biological adverse effects, and allergic reactions in humans. For consumer protection, determination of this antibiotic in honey samples is of considerable importance.

Many analytical studies for the determination of tetracyclines residues in honey have been described. However, due to the complexity of this matrix, it is difficult to obtain a sufficiently sensitive method for honey. To remove the matrix effect, a more rigorous clean-up procedure is required. The analysis of OTC in honey is carried out using HPLC with different detection methods, such as ultraviolet (Sporns et al., 1986; Oka et al., 1987; Vinas et al., 2004; Victorita et al., 2007), fluorescence (Argauer and Moats, 1991; Pena et al., 2005; Fujita et al., 2008; Peres et al., 2010), and mass spectrometry (Khong et al., 2005). Only a little information is available concerning the effect of storage on OTC residues in honey after hive treatment (Thompson et al., 2005). fective analytical method for the analysis of OTC in honey. Additionally, the

The aim of this study was to improve on the previously described (Zhou et al., 2009) selective and efdepletion time after experimental administration of OTC to honeybee colonies by liquidsucrose-solution dosing was studied. The stability of OTC in honey under laboratory conditions was also examined.

\section{MATERIAL AND METHODS}

\section{Reagents}

All reagents used were of analytical grade. The oxytetracycline (OTC) standard with a $99 \%$ degree of purity, was obtained from Sigma-Aldrich Chemical Company (USA). Acetonitrile, methanol, and Bakerbond SPE cartridges (carboxylic acid $500 \mathrm{mg} / 3 \mathrm{ml}$ ) were from J.T. Baker. Oxalic acid dihydrate (ACS) was from POCh Gliwice (Poland). Strata X (100 mg, 3ml) polymeric cartridges were from Phenomenex. Additionally, ethyl acetate was obtained from POCh (Poland). Water was purified using the Milli-Q system.

\section{Standard solutions}

Stock standard solution (1 $\mathrm{mg} / \mathrm{mL})$ which had been prepared by weighing $10.0 \pm 0.1 \mathrm{mg}$ of standard substances and dissolving them in $10 \mathrm{ml}$ of methanol, was stable for six months when stored at a temperature below $-18^{\circ} \mathrm{C}$ in amber glass. Working standard solutions $(100 \mu \mathrm{g} / \mathrm{mL}$, $10 \mu \mathrm{g} / \mathrm{mL}$ ) prepared in acetonitrile by diluting suitable aliquot of stock standard were stable for one month, stored at $2-8^{\circ} \mathrm{C}$ in amber glass. Working standard solutions in the mobile phase were prepared on the day of analysis.

\section{Extraction and two-step clean-up}

Three grams of honey were mixed with $20 \mathrm{ml}$ of $0.02 \mathrm{M}$ oxalic acid buffer, $\mathrm{pH}$ 4.0. This mixture was then vortexed for $5 \mathrm{~min}$. and put in an ultrasonic bath to mix well for $15 \mathrm{~min}$. After the extraction procedure, the supernatant was poured into Strata X polymeric columns which were earlier preconditioned with $5 \mathrm{ml}$ methanol and a $10 \mathrm{ml}$ extraction buffer solution. After percolation of the whole solution, the columns was washed with $10 \mathrm{ml}$ of $5 \%$ methanol in water and dried (under vacuum) for $10 \mathrm{~min}$. Finally, the analytes were eluted from the polymeric cartridges with $15 \mathrm{ml}$ ethyl acetate. The ethyl acetate eluate was transferred into a carboxylic acid cartridge, previously conditioned with $5 \mathrm{ml}$ ethyl acetate. The cartridge was washed with $10 \mathrm{ml}$ methanol and dried completely. The oxytetracycline was eluted with $4 \mathrm{ml}$ mixture of $0.02 \mathrm{M}$ oxalic acid ( $\mathrm{pH} 2.0)$ and acetonitrile $(6: 4, \mathrm{v} / \mathrm{v})$. The eluate was evaporated to a $2 \mathrm{ml}$ volume under a stream of nitrogen at $40{ }^{\circ} \mathrm{C}$. After vortex mixing, the solution was ready to analyse.

\section{LC-UV analysis}

The instrumental analysis was performed using the Varian Prostar HPLC system, equipped with a quaternary pump, autosampler, column oven, and UV/Vis detector $(\lambda=355 \mathrm{~nm})$, controlled by Galaxie Workstation software. Chromatographic 
analyses were performed on Luna (Phenomenex) C8 column $(5 \mu \mathrm{m}, 250 \mathrm{~mm}$ $\mathrm{x} 4.6 \mathrm{~mm}$ ) with mobile phase consisting of (A) acetonitrile : (B) $0.02 \mathrm{M}$ oxalic acid ( $\mathrm{pH} 4.0$ ) in gradient mode at $1.0 \mathrm{ml} / \mathrm{min}$ flow rate. A gradient elution program was started from $16 \%$ of A. After 1 min., an increase was done to $25 \%$ of A up to 5 min., and at $5 \mathrm{~min}$. to $10 \mathrm{~min}$. a decrease to $16 \%$ was done and kept for $3 \mathrm{~min}$. The column oven temperature was controlled at $30{ }^{\circ} \mathrm{C}$. The injection volume of $100 \mu \mathrm{l}$ was used.

\section{Validation}

Samples of honey were spiked with the OTC working solution to levels corresponding to $12.5,25$, and $50 \mu \mathrm{g} / \mathrm{kg}$, respectively. The recovery was evaluated by comparing the concentrations in the spiked samples having known amounts of analyte, to the concentrations in standard solution. The six spiked samples with OTC were analysed within three different days. Based on these spiked sample replicates, the precision (repeatability and reproducibility) of the method was determined. Linearity was tested by preparing amatrix-matched calibration curve on five levels corresponding to 12.5 , $25,50,75$, and $100 \mu \mathrm{g} / \mathrm{kg}$. The correlation coefficient was evaluated. The detection limits (LOD) and limit of quantification (LOQ) of the method were calculated. Additionally, during the validation process, the decision limit $(\mathrm{CC} \alpha)$ and detection limit $(\mathrm{CC} \beta)$ were evaluated.

\section{Bee colonies and treatment}

Colonies of honeybees (Apis mellifera) were maintained and owned by the Department of Honey Bee Diseases of the National Veterinary Institute in Puławy, Poland. The colonies were housed in wooden hives and were allowed free flight during the study. The hives had frames which were: $360 \times 260 \mathrm{~mm}$ (length $\mathrm{x}$ height). None of the colonies showed clinical signs of disease. Before the start of experiment, OTC analyses were realized on honey collected in every comb of every hive. Bees from three colonies (hive 1 , hive 2 , hive 3 ) were fed with 1 litre saccharose syrup containing OTC. The syrup was prepared by mixing $0.5 \mathrm{~g}$ of OTC in a 1 litre sugar (saccharose/water 50:50 $\mathrm{v} / \mathrm{v}$ ) solution. Dosing of OTC was initiated at the end of June and repeated two times - every 7 days. Bees from hive 4 received saccharose syrup without OTC. Honey samples were taken from the frames in the hives prior to the beginning of the dosing, and at 1 and 12 months after the end of the dosing. The honey samples were collected from each hive separately and filtered through cloth into a clean glass jar labelled with the colony number, then stored at an ambient temperature before being analysed. To determine the stability of OTC in honey under laboratory conditions, samples from the first collection were kept at $20^{\circ} \mathrm{C}$ and analysed for 17 months.

\section{RESULTS}

The specificity of the method was checked by analyzing different types of honey samples. No interfering peaks were detected in the OTC retention time. The typical HPLC chromatograms of blank sample and sample spiked with OTC are shown in Fig. 1. In this method, the separation was made using C8 analytical column, with a mobile phase containing acetonitrile and $0.02 \mathrm{M}$ oxalic acid. A sharp, symmetrical peak was obtained. The two step clean-up system with polymeric

\section{Table 1 .}

Validation results of analytical procedure for the determination of oxytetracycline in honey

\begin{tabular}{|c|c|c|c|}
\hline Parameters & \multicolumn{3}{|c|}{ Results } \\
\hline Compound & \multicolumn{3}{|c|}{ Oxytetracycline } \\
\hline Correlation coefficient $(r)$ & \multicolumn{3}{|c|}{0.9994} \\
\hline Linearity (working range), $\mu \mathrm{g} / \mathrm{kg}$ & \multicolumn{3}{|c|}{$12.5-100$} \\
\hline Detection limit (LOD), $\mu \mathrm{g} / \mathrm{kg}$ & \multicolumn{3}{|c|}{10} \\
\hline Limit of quantification (LOQ), $\mu \mathrm{g} / \mathrm{kg}$ & \multicolumn{3}{|c|}{12.5} \\
\hline Decision limit $(\mathrm{CC} \alpha, \mu \mathrm{g} / \mathrm{kg})$ & \multicolumn{3}{|c|}{29.8} \\
\hline Detection capability $(\mathrm{CC} \beta, \mu \mathrm{g} / \mathrm{kg})$ & \multicolumn{3}{|c|}{35.9} \\
\hline Level of spiked samples $(\mu \mathrm{g} / \mathrm{kg})$ & 12.5 & 25 & 50 \\
\hline Repeatability, CV\% $(\mathrm{n}=6)$ & 3.8 & 4.2 & 5.7 \\
\hline Reproducibility, CV\% ( $n=18)$ & 4.9 & 6.5 & 7.9 \\
\hline Recovery, \% & 75.4 & 74 & 71 \\
\hline
\end{tabular}


a)

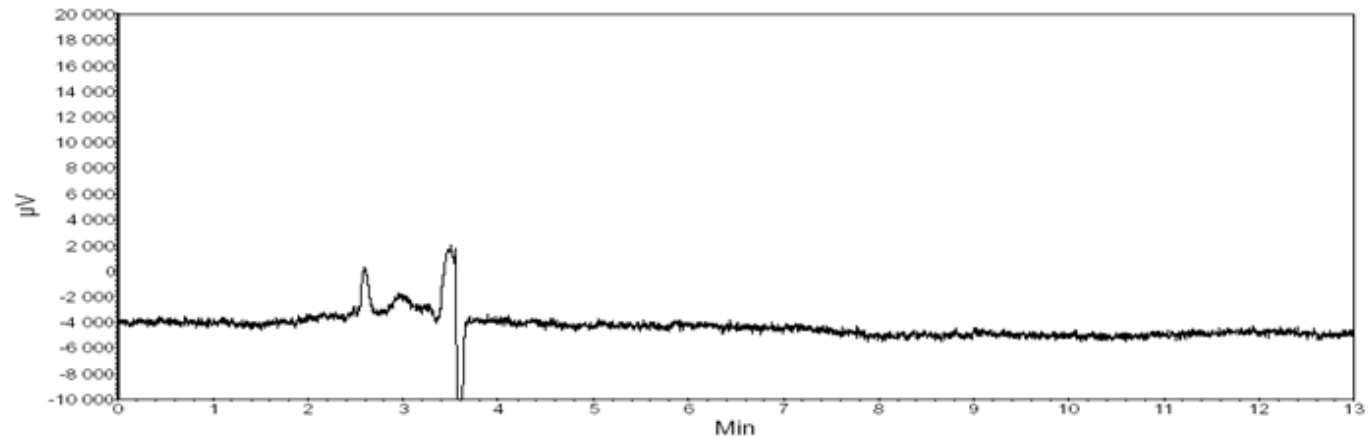

b)

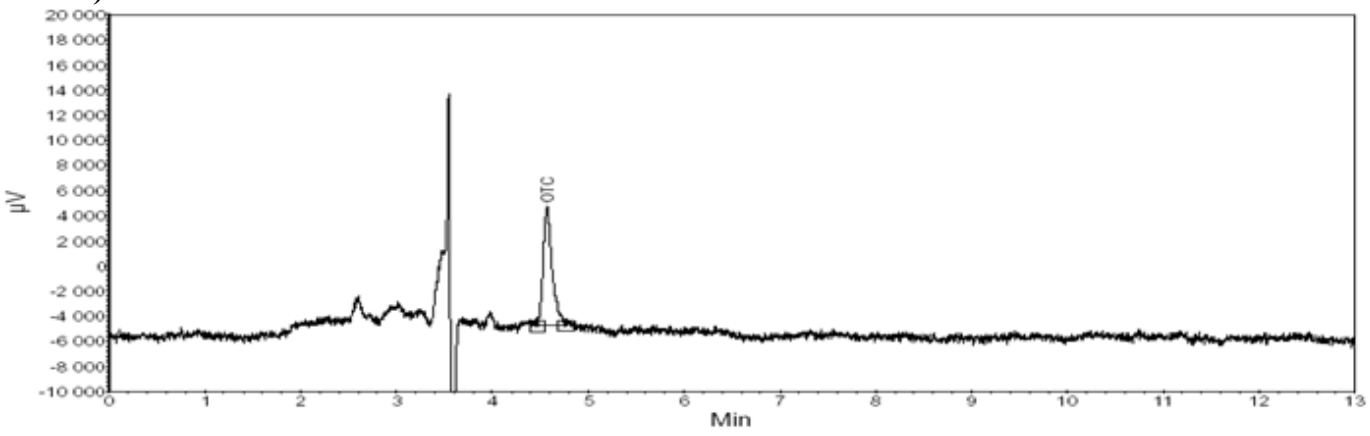

c)

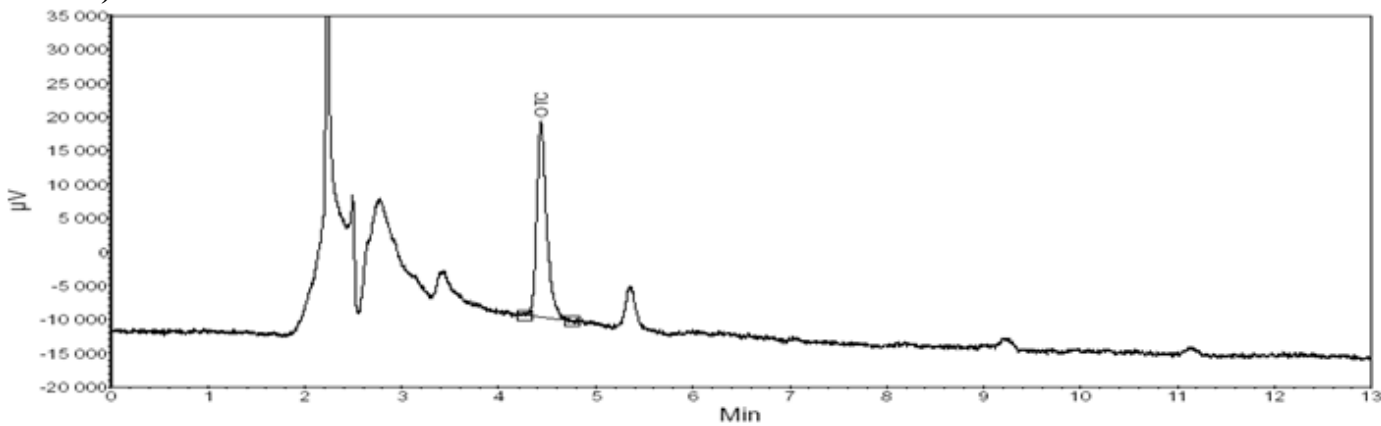

Fig. 1. Typical chromatograms of: a) blank honey sample; b) honey sample spiked with OTC at LOQ level; c) honey sample after OTC treatment.

and carboxylic SPE columns was found suitable for purification purposes. The use of the $355 \mathrm{~nm}$ wavelength $(\lambda)$ was the most appropriate for oxytetracycline.

During the validation process, the limit of detection (LOD), and limit of quantification (LOQ) were established. Linearity and detection parameters, and precision and recovery of the method are shown in Table 1. The variation coefficients and mean extraction recoveries are satisfactory. The method was linear and showed good precision.
After experimental medication of OTC to honeybee colonies, all honeys showed positive results by HPLC with concentration ranges from $17300 \mu \mathrm{g} / \mathrm{kg}$ to $34000 \mu \mathrm{g} / \mathrm{kg}$ at the first month after treatment. In honey harvested from colonies after 12 months (one overwintering period), the concentration of OTC was below LOD of the method. In the control colonies no OTC was detected. The stability data of OTC in honey under laboratory conditions are presented in Table 2. In honey stored at an ambient temperature, the concentration 
Stability of oxytetracycline in honey stored under laboratory conditions

\begin{tabular}{||l|c|c|c||}
\hline \multirow{2}{*}{ Date of analysis } & \multicolumn{3}{|c|}{ Concentrations of } \\
& oxytetracycline in honey [ $\mathrm{\mu g} / \mathrm{kg}]$ \\
\cline { 2 - 4 } & Hive 1 & Hive 2 & Hive 3 \\
\hline July 2009 & 17300 & 26100 & 34000 \\
\hline September 2009 & 4600 & 5900 & 8900 \\
\hline January 2010 & 1450 & 1240 & 1990 \\
\hline June 2010 & 780 & 680 & 840 \\
\hline December 2010 & 348 & 268 & 425 \\
\hline
\end{tabular}

of OTC slightly decreased and the honey was analysed for a period of 17 months after treatment.

\section{DISCUSSION}

Honey is a very complex matrix to analyse. It contains several organic and inorganic constituents. Among them are: glucose and fructose $(75 \%)$, oligo saccharides, vitamins, aliphatic acids, amino acids, and proteins. Due to the composition of the honey matrix, it is difficult to obtain sufficient sensitivity in a method, especially when classic detectors are used.

A crucial point in drug residue analysis is the sample extraction step, which requires the isolation of the residues from a biological matrix. The effective isolation of OTC residues from honey is more difficult, because the OTC is high polar molecule and binds with sample proteins. Additionally this compound connects with metal ions. In many studies for the determination of tetracyclines in honey, an extraction using sodium acetate buffer (Huq et al., 2006), McIlvaine - EDTA buffer (Oka et al., 1987; Vinas et al., 2004; Pena et al., 2005; Zhou et al., 2009), sodium succinate buffer (V ictorita et al., 2007), and oxalate buffer (Khong et al., 2005) was used to overcome these undesirable properties. The value of $\mathrm{pH}$ extraction buffer has a big influence on the chemical behaviour of tetracyclines. Three $\mathrm{pH}$ values of oxalic acid buffer (2.0, 4.0, and 6.0) were tested in the present work.
The best results were obtained with oxalic acid $\mathrm{pH}$ 4.0. Additionally, the use of hexane for the elimination of the honey endogenous compounds adsorbed on the column was checked, but the results were not satisfactory.

To success of analytical method is to achieve clean sample after sample preparation step. The use of combination neutral polymeric sorbent and weak cation exchange (carboxylic) sorbent was described for determination of tetracycline in propolis (Zhou et al., 2009). A more detailed study on clean-up efficiencies with a weak cation exchange polymeric sorbent (strata X-CW) and a combination of neutral and strong cation exchange sorbent (strata $\mathrm{X}$ plus Strata-Screen-C or strata X-C was reported (Huq et al., 2006). It was also proposed and described metal chelate affinity column (MCAC) in clean-up procedure for determination tetracyclines residues in honey (Thompson et al., 2005; Fujita et al., 2008) or application DSC-phenyl SPE cartridges (V in as et al., 2004). When only neutral polar polymeric sorbent was used, the interference peaks due to matrix effect by LC-MS/MS were observed (Khong et al., 2005).

In our study, during clean-up optimization, different kind of sorbents and cartridges for clean up efficacy were compared. After the use of $\mathrm{C} 18$ sorbent or nexus cartridges, the extract was not clean enough with many interferences and too low recovery. Two polymeric packings: Oasis HLB and Strata X was tested, separately. However, these cartridges were not efficient in eliminating the honey 
matrix constituents. As it was found, the use of two step clean-up with Strata X and carboxylic acid columns was most efficient because of the cleanest extract.

In several studies it have been presented the usage of $\mathrm{C} 18$ analytical columns (Pena et al., 2005; Huq et al., 2006; Zhou et al., 2009), PLRP-S (Argauer and Moats, 1991; Thompson et al., 2005) or Amide C16 column to analyse tetracyclines in honey (Vin as et al., 2004). In our method, the C8-bonded silica column was used based on the results of Neils and De Leenheer (1980), who preferred this packing to the more common $\mathrm{C} 18$ material (Sporns et al., 1986; Peres et al., 2010). Tetracycline can form chelate complexes on the reversed - phase column and they can appear as tailing peaks. In order to avoid these properties and obtain symmetrical, non - tailed peaks, oxalic acid as mobile phase is recommended (Oka et al., 1987; Vinas et al., 2004; Zhou et al., 2009).

The experimental administration of OTC to honeybee colony showed, that OTC is transferred to honey in high concentration (up to $34,000 \mu \mathrm{g} / \mathrm{kg}$ ). OTC is not very stable in honeybee combs and the level of this compound quite fast decline. Based on the Dinkov et al. results study, the estimated elimination half-life for OTC in honey after bees treatment was 38.37 days (Dinkov et al., 2005). Some experiments were done to determine the stability of OTC in honey and aqueous systems (OTC half-life) depending on buffer $\mathrm{pH}$ and temperature. It was found that OTC in honey is almost five times as stable as OTC in diluted honey (Sporns et al., 1986). According to Martel et al. (2006) study, at $35^{\circ} \mathrm{C}$, which is the internal hive temperature, the degradation of tetracycline (TC) is twice faster than at ambient temperature. A half-life for this compound (at $35^{\circ} \mathrm{C}$ in the dark) was estimated as 121 days. The stability of TCs after 60 days of storage in honey samples fortified at $500 \mu \mathrm{g} / \mathrm{kg}$ was evaluated by Peres et al. (2010). Thompson et al. (2005) reported, that the time for OTC residues to decline to the LOQ of $0.05 \mathrm{mg} / \mathrm{kg}$ is approx 14 - 16 weeks. It was also suggest, that OTC method of application has big influence on OTC residues in honey. Application as a powdered icing sugar results in lower concentration level than dosing in liquid sucrose.

\section{CONCLUSION}

The HPLC-UV method, described in this study, was developed to analyse the residues of OTC in honey samples. The two step clean-up procedure was found suitable to obtain extract clear enough without any interferences. The satisfactory validation results and verification of presented method in experiment proved that proposed method is sensitive enough and suitable for routine identification of OTC in honey. It was also found that OTC duration in honey stored in laboratory was longer than in hives.

\section{REFERENCES}

Argauer R. J., Moats W. A. (1991) Degradation of oxytetracycline in honey as measured by fluorescence and liquid chromatographic assays. Apidologie, 22: 109-115.

Commission Decision 2002/657/EC of 12 August 2002 implementing Council Directive 96/23/EC concerning the performance of analytical methods and the interpretation of results. Off. J. Eur. Commun. 2002, L 221, pp. 8-36.

Commission Regulation (EU) No $37 / 2010$ of 22 December 2009 on pharmacologically active substances and their classification regarding maximum residue limits in foodstuffs of animal origin. Off. $J$. Eur. Commun. 2010, L 15, pp. 1-72.

Dinkov D., Kanelov I., Zhelyazkova I., Vashin I. (2005) - Persistence of tetracycline and oxytetracycline in bee honey after improper application on bee families. Bulg. $J$. Vet. Med., 8(3): 205-509. 
European Medicines Agency

Veterinary Medicines and Inspections: Summary opinion of the committee for medicinal products for veterinary use on the establishment of Maximum Residue Limits - Oxytetracycline (Extension to honey bees), EMEA/CVMP/581586/2008.

Fujita K., Ito H., Ishihara M., Inukai S., Tanaka H., Taniguchi M. (2008) - Analysis of trace residues of tetracyclines in dark-colored honeys by highperformance liquid chromatography using polymeric cartridge and metal chelate affinity chromatography. J. Food Hyg. Soc. Japan, 49(3): 196-203.

Gojmerac W. L. (1980) - Enemies of honey bees, in: Gojmerac W. L. (Ed.) Bees, beekeeping, honey and pollination, Avi Pub. Co., Westport, pp. 127-137.

Huq S., Garriques M., Kallury K. M. R. (2006) - Role of zwitterionic structures in the solid-phase extraction based method development for clean up of tetracycline and oxytetracycline from honey. J. Chromatogr. A., 1135: 12-18.

Khong S. P., Hammel Y. A, Guy P. A. (2005) - Analysis of tetracyclines in honey by high-performance liquid chromatography/ tandem mass spectrometry. Rapid Commun. Mass Spectrom., 19: 493-502.

Martel A. C., Zeggane S., Drajnudel P., Faucon J. P., Aubert M. (2006) Tetracyclines residues in honey after hive treatment. Food Addit. Contam., 23(3): 265273.

Neils H. J., De Leenheer A. P. (1980) Retention mechanisms of tetracyclines on a C8 reversed-phase material. J. Chromatogr., 195: 35-42.

Oka H., Ikai Y., Kawamura N., Uno K., Yamada M. (1987) - A simple method for residual tetracyclines analysis in honey using a tandem cartridge clean-up system. J. Chromatogr., 389: 417-426.
Pena A., Pelantova N., Lino C. M., Silveira M. I. N., Solich P. (2005) - Validation of an analytical methodology for determination of oxytetracycline and tetracycline residues in honey by HPLC with fluorescence detection. J. Agric. Food Chem., 53: 3784-3788.

Peres G. T., Rath S., Reyes Reyes F. G. (2010) - A HPLC with fluorescence detection method for the determination of tetracyclines residues and evaluation of their stability in honey. Food Control, 21: 620-325.

Regulation (EC) No 470/2009 of the European Parliament and of the Council of 6 May 2009 laying down Community procedures for the establishment of residue limits of pharmacologically active substances in foodstuffs of animal origin, repealing Council Regulation (EEC) No 2377/90 and amending Directive 2001/82/EC of the European Parliament and of the Council and Regulation and of the Council and Regulation (EC) No 726/2004 of the European Parliament and of the Council. Off. J. Eur. Commun. 2009, L 152, pp. 11-22.

Sporns P., Kwan S., Roth L. A. (1986) - HPLC analysis of oxytetracycline residues in honey. J. Food Prot., 49(5): 383-388.

Thompson H. M., Waite R. J., Wilkins S., Brown M. A., Bigwood T., Shaw M., Ridgway Ch., Sharman M. (2005) - Effects of European foulbrood treatment regime on oxytetracycline levels in honey extracted from treated honeybee (Apis melifera) colonies and toxicity to brood. Food Addit. Contam., 22(6): 573-578.

USFDA (US Food and Drug Administration). Center for veterinary medicine database of approved animal drugs. Animal drugs @ FDA. October 1, 2008. [online] http://www. accessdata.fda.gov/scripts/animaldrugsatfda/ (accessed on September 2009).

Victorita B., Marghitas L. A., Dezmirean D., Moise A., Bobis O., Maghear O. (2007) - Optimization of HPLC method for quantifying tetracycline residue in honey. Bull. USAMV-CN, 64(1-2). 
Vinas P., Balsalobre N., Lopez- Zhou J., Xue X., Zhang Y. L. J., Erroz C., Hernandez-Cordoba M.(2004) Chen F., Wu L., Chen L., Zhao J. - Liquid chromatography with ultraviolet (2009) - Multiresidue determination of detection for the analysis of tetracycline tetracycline antibiotics in propolis by using residues in honey. J. Chromatogr. A, 1022: HPLC-UV detection with ultrasonic- assisted 125-129. extraction and two-step solid phase extraction. Food Chem., 115: 1074-1080.

\title{
ANALIZA POZOSTALOŚCI OKSYTETRACYKLINY W MIODZIE METODĄ CHROMATOGRAFII CIECZOWEJ Z DETEKTOREM UV
}

\author{
Gajda A., Posyniak A., Bober A., \\ Błądek T., Żmudzki J. \\ S t r e s z c z e n i e
}

Opracowano metodę chromatografii cieczowej z detektorem UV do oznaczania oksytetracykliny (OTC) w miodzie. Do ekstrakcji próbek wykorzystano roztwór kwasu szczawiowego. Do oczyszczania zastosowano zestaw ekstrakcji do fazy stałej (SPE) z użyciem kolumienek polimerycznych Strata X oraz kolumienek karboksylowych. Rozdziału chromatograficznego dokonano przy użyciu kolumny analitycznej Luna C8 z faza ruchomą składającą się z acetonitrylu i $0.02 \mathrm{M}$ roztworu kwasu szczawiowego. Metoda została zwalidowana zgodnie z wymogami Decyzji Komisji Europejskiej 2002/657/EC i jest stosowana w rutynowych badaniach kontrolnych oksytetracykliny $\mathrm{w}$ próbkach miodu. Opracowana metoda została zweryfikowana w ilościowym oznaczaniu pozostałości oksytetracykliny w miodzie po eksperymentalnym podaniu pszczołom tego antybiotyku. Celem przeprowadzonego doświadczenia było określenie, jak długo oksytetracyklina może pozostawać w miodzie. Badano także stabilność oksytetracykliny w warunkach laboratoryjnych. Wyniki badania stabilności wskazują, że oksytetracyklina w miodzie przechowywanym w warunkach laboratoryjnych ulega powolnemu zmniejszaniu. W pobranych do badań próbkach miodu stwierdzono zawartość OTC w stężeniach od $17300 \mu \mathrm{g} / \mathrm{kg}$ do $34000 \mu \mathrm{g} / \mathrm{kg}$. Przeprowadzone badania wskazują, że OTC w znacznych ilościach przedostaje się do miodu po jej zastosowaniu u pszczół. Po 12 miesiącach od podania antybiotyku pszczołom, stężenie w miodzie było poniżej wyznaczonej granicy wykrywalności metody $(10 \mu \mathrm{g} / \mathrm{kg})$.

Słowa kluczowe: oksytetracyklina, miód, pozostałości, walidacja, zanikanie, metoda HPLC-UV. 